\title{
Euro Bölgesinde İşsizlik Histerezisinin İkinci Nesil Panel Birim Kök Testleri ile Analizi*
}

\author{
Analysing Unemployment Hysteresis in Eurozone with the Second \\ Generation Panel Unit Root Tests
}

\author{
Yrd. Doç. Dr. Bülent Doğru
}

\begin{abstract}
Öz
Bu çalışmanın amacı 1999 yılından beri ortak para birimi Euro'yu kullanan $12 \mathrm{AB}$ ülkesinin işsizlik oranlartnin histerezis etkisi gösterip göstermediğini yani durağan olup olmadikları 1980-2012 arası dönemde ikinci nesil panel birim kök testleri ile analiz etmektir. Çalışmada yatay kesit bağımlılı̆̆ın dikkate alan SURADF ve CADF panel birim kök testleri ile analiz yapılmıştır. Elde edilen ampirik bulgulara Yunanistan, İrlanda ve Avusturya için SURADF testi; Portekiz, Yunanistan ve Avusturya için ise CADF testi histeri etkisine işaret etmektedir. Yani bu ülkelerin işsizlik serileri durağan değildir, birim kök içermektedir. Diğer 9 ülkede işsizlik serileri durağandır, işsizlikte histeri etkisinin varlığ kabul edilmemektedir. Bu ülkelerde geçici şoklar kalıcı etkiler bırakmamaktadır. Şoklar, istihdamda yapısal dönüşümlere yol açmamaktadır. Bu sonuçlar Euro bölgesinin çoğunda histeri önsavının değil, doğal işsizlik oranı önsavının geçerli olduğunu ortaya koymaktadır.
\end{abstract}

Anahtar Kelimeler: İsssizlik histerisi, SURADF, CADF, Euro Bölgesi

\section{Abstract}

This paper tests unemployment hysteresis using second generation panel unit root tests for 12 European Union countries using the Euro as a common currency for the time period 1999-2012. The analyzes are performed with SURADF and CADF panel unit root test taking into account the cross-sectional dependence between individuals. The empirical findings of SURADF test indicate the effect of hysteria for countries Portugal, Greece and Austria, and the empirical findings of CADF
\end{abstract}

test indicate the effect of hysteria for countries Greece, Ireland and Austria. Namely, unemployment series of these countries are not stationary, they contain unit root. For the other 9 countries, the unemployment series is stationary; the existence of the hysteresis effect in unemployment is not accepted. In these countries, temporary shocks do not leave lasting effects. Shocks do not lead to structural transformations on employment. This results reveals that in most of the euro zone's countries, not hysteria hypothesis but the natural rate of unemployment hypothesis is valid.

Keywords: Unemployment hysteresis, SURADF, CADF, Eurozone

\section{Giriş}

1970’lerde baş gösteren petrol krizinin yarattığg arz şoku Avrupa ülkeleri dahil birçok ülkede istihdamın azalmasına ve işsizlik oranlarının artmasına yol açmıştır. İşsizliğin yapısal ya da konjonktürel yapısı hakkında yapılan çalışmaların sayısı bu tarihten sonra artmıştır. Bu çalışmalar arasında Friedman (1968), Phelps $(1968,1994)$, Blanchard ve Summers (1986), Brunello (1990) ve Christopoulos ve LeonLedesmảnın (2007) çalışmaları başı çekmektedir. Birçok yazar petrol şokunun kalıcı mı geçici mi olduguna dair çeşitli hipotezler ortaya sürmüşlerdir. Geçici şokların işsizlik üzerine etkisi iki teori bağlamında analiz edilmektedir: Doğal işsizlik oranı teorisi ve histeri teorisi. Doğal işsizlik oranı savı Friedman ve Phelps'e (1968) aittir. Friedman ve Phelps'e göre işsiz-

Yrd. Doç. Dr. Bülent Doğru, Gümüşhane Üniversitesi İİBF, buldogru@gmail.com

* Bu çalışma Econanadolu2013 Uluslararası İktisat Kongresi’nde sunulmuştur. 
liğe yol açan dinamikler kalıcı değil geçici bir etkiye sahiptir. Bu yazarlara göre cari işsizlik düzeyi uzun dönemde doğal işsizlik düzeyine (non-accelerating inflation rate of unemployment-nairu) doğru yakınsamaktadır.

Histeri önsavını savunan Blanchard ve Summers (1986) ise konjonktürel arz şoklarının işsizliği yapısal değişimlere uğratarak uzun dönemde işsizlik üzerinde kalıcı bir etkiye sahip olacağını ve doğal işsizlik haddini yukarı çekeceğini öne sürmüşlerdir. İșsizlik histerisi olarak adlandırılan bu mekanizma kısaca işsizlik oranlarının durağan olmaması, birim kök içermesi ile açılanmaktadır. Bir diğer deyişle işsizlik histerisi işsizlik oranlarının uzun dönemde bir denge düzeyine yakınsamak yerine dengeden uzaklaşan bir görüntü sergilemesidir. Daha sonra gelen yazarlar, Blanchard ve Summers'in yolundan giderek bir ülkede uzun süre devam eden yüksek işsizlik düzeyinin zaman içinde kalıcı hale geleceğini ve işgücünün azalacağını öne sürmüşlerdir. Böylece yaşanılan bir şokun işgücü oranında kalıcı bir etkiye sahip olacağını ve işsizliğin başlangıçtaki denge seviyesine geri dönemeyeceğini savunmuşlardır (Christopoulos ve León-Ledesma, 2007, s.81; Yllanc1, 2011).

Bu çalışmanın amacı ortak para birimi Euróyu kullanan $12 \mathrm{AB}$ ülkesindeki istihdamın histerisi etkisi gösterip göstermediğini yatay kesit bağımlılığını dikkate alan ikinci nesil panel birim kök testleri analiz etmektir. Zaman boyutunun ülke sayısından büyük olması $(\mathrm{T}>\mathrm{N})$ durumunda Breuer vd. (2002) tarafindan geliştirilen SURADF (Seemingly Unrelated Regression Augmented Dickey Fuller) testi ve Pesaran (2006) tarafından geliştirilen CADF (Cross-sectionally Augmented Dickey Fuller) panel birim kök testleri ile analiz edilmiştir.

Çalışmanın ampirik bulguları birlikte değerlendirildiğinde, hem CADF hem de SURADF panel birim kök test sonuçları çoğunlukla histeri önsavına karşı doğal işsizlik oranı önsavının desteklendiğini göstermektedir. Oniki ülkenin dokuzunda işsizlik serisi durağan çıkmıştır. İşsizlik serileri Yunanistan'da ve İrlanda'da CADF testine göre, Portekiz'de SURADF testine göre, Avusturya'da ise her iki teste göre durağan değildir. $\mathrm{Bu}$ sonuçlar Camarero ve Tamarit (2004), Feve vd. (2003), Arestis ve Mariscal (2000) ve Chang vd. (2005) ile paralellik arz etmektedir. Bu sonuçlar, 2008 küresel krizinin histeri önsavını destekleyecek boyutta yapısal dönüşümlere yol açmad1ğını da göstermektedir.
$\mathrm{Bu}$ çalışmanın diğerlerinden farkı Euro para birimini kullanan ülkeler topluluğu (Eurozone) üzerine yapılmış az sayıda çalışmadan bir tanesi olması ve 2008 küresel krizinin istihdam üzerindeki şok etkisini ölçmeye çalışmasıdır. Buradan elde edilecek sonuç Euro bölgesindeki işsizliğin kendi kendini doğurup doğurmadığına (inertia özelliği), yapısal değişimlerden kaynaklanıp kaynaklanmadığına veya konjonktürel bir işsizlik sorunu ile karşı karşıya olduğumuza dair ipuçları verecektir. Daha da önemlisi Blanchard ve Summers’n öngördüğü gibi 2008 küresel finans krizinin de 1970’lerdeki petrol şoku gibi Euro Bölgesindeki işsizlik oranlarında kalıcı bir etkiye yol açıp açmadığı belirlenmeye çalışılmaktadır.

Çalışmanın devamı şöyledir: 2. Bölümde işsizlik histerisi üzerine yapılan ampirik çalışmalardan bazılarına değinilmektedir. 3. Bölümde çalışmamın metodolojisi yani ikinci nesil birim kök testleri teorik olarak anlatılmaktadır. Dördüncü ve beşinci bölümlerde s1rasiyla kullanılan veriler ve birim kök testlerinin tahmin sonuçları yer almaktadır. Çalışma sonuç kısmı ile sona ermektedir.

\section{Literatür}

İsizizlik histerisinin tekil ülkeler ya da ülke grupları için sağlanıp sağlanmadığını test eden çok sayıda çalışma vardır. Özellikle OECD ülkelerini konu alan çalışma sayısı oldukça fazladır. Bunların bir kısmına aşağıda özet şekilde yer verilirken diğerleri özet bir tablo halinde analiz edilen dönem, ekonometrik metot, ülke(ler) ve test sonucunu bir arada gösterecek şekilde Tablo l'de sunulmaktadır. Bu çalışmalarda kullanilan teknik genel olarak 1. nesil ve 2. nesil panel birim kök testleri ile yapısal kırılmalı zaman serisi birim kök testleridir. $\mathrm{OECD}, \mathrm{AB}$ ve diğer ülkeler üzerine yapılan çalışmalardan bazıları kısaca şöyledir:

Ayala (2012), işsizliğin dinamiklerini ve işsizlik histerisini 18 Latin Amerika ülkesi (Arjantin, Barbados, Bolivya, Brezilya, Şili, Kolombiya, Kosta Rika, Dominik Cumhuriyeti, Ekvador, Guatemala, Jamaika, Meksika, Panama, Paraguay, Peru, Trinidad Tobago, Uruguay ve Venezüella) özelinde 1970-2009 dönemi boyunca zaman serisi tekniklerini kullanarak analiz etmiştir. Çalışmanın sonuçları, Latin Amerika ülkelerinde işsizlik histerisinin varlığını desteklemektedir.

Lee ve Chang (2008), yaklaşık bir asırlık zaman dilimini kapsayan çalışmalarında işsizlik histerisi hi- 
potezini 14 büyük OECD ülkesi için Lagrange Multiplier birim kök testi yardımıyla analiz etmişlerdir. Çalışmanın ampirik bulgularına göre yapısal kırılma dikkate alındığında 14 OECD ülkesinde işsizlik oranı durağanlık göstermektedir, yani histerisi etkisi yoktur. Ancak yapisal kırılmaya izin vermeyen zaman serisi testlerinden elde edilen sonuçlar bu bulguların aksi yönündedir.

Liew, Chia ve Puah (2009), Ocak 1993- Mayıs 2007 dönemini kapsayan çalışmalarında işsizlik histerisi hipotezini 14 OECD ülkesi üzerinde panel birim kök testleri ile analiz etmişlerdir (Maddala ve Wu (1999), Choi (2001), Im vd. (2003) ve Levin vd. (2002) birim kök testleri). Ampirik sonuçlara göre işsizlik histerisi hipotezi OECD ülkelerinin çoğunda doğrulanmaktadır.

Camarero vd. (2006), 1956-2001 döneminde işsizlik histerisinin varlığını 19 OECD ülkesin için panel data yöntemleri ile analiz etmişlerdir. Çalışmanın sonucuna göre OECD ülkelerinin çoğunda işsizlik histerisi etkisi olmasına rağmen bazı ülkelerde bu olguya rastlanmadığı sonucuna varılmıştır.

Chang (2011) da 17 OECD ülkesi için 1960-2009 dönemi özelinde işsizlik histerisinin varlığını test etmiştir. Becker vd. (2006) tarafından önerilen Fourier Fonksiyonun durağanlık testi ile işsizlik serisinde birim kök olup olmadığını analiz eden Chang (2011) da Camarero vd. (2006) gibi OECD ülkelerinin çoğunda işsizlik histerisinin sağlandığını ortaya koymuştur.

Strazicich, Tieslau ve Lee (2001) de ikinci dünya savaşı ile 2000 yılı arasındaki süreçte 19 OECD ülkesinin işsizlik oranlarında histerezis etkisinin olup olmadığını yapısal değişmeleri dikkate alan panel LM birim kök testleri ile ampirik olarak test etmiştir. Çalışmanın sonuçları daha önceki çalışmalarla paralellik arz etmektedir: Histerezis etkisi işsizlik oranlarında vardır.

$\mathrm{Bu}$ çalışmaların dışında işsizlik histerisini OECD ve $\mathrm{AB}$ ülkeleri özelinde inceleyen oldukça fazla sayıda yazar vardır. Lee ve Chang (2008), bu çalışmaların özet bir listesine çalışmalarında sunmuşlardır. Tablo l'de raporlanan bu çalışmalarda, genel olarak işsizlik histerezisinin varlığı tekil ülkeler için ADF, KPSS birim kök testleriyle; ülke grupları için ise LL, IPS, Panel SURADF ve diğer yapısal kırılmalı panel birim kök testleri ile analiz edilmiştir. Sonuçlara bakıldığında incelenen analiz dönemine ve kullanılan ampirik yönteme bağlı olarak her çalışmada farklı bir ülkenin işsizlik histerezisi olgusu taşıdığını, ancak genel olarak
Amerika (USA), İngiltere (UK), Almanya, Belçika ve Avusturalya gibi ülkelerde histerezis etkisinin görülmediği ortaya çıkmaktadır. Buralardaki işsizlik konjonktürel şoklardan kaynaklanmaktadır ve geçicidir.

Bu çalışmaların dışında Türkiye'de işsizlik histerisinin varlığını araştıran az sayıdaki çalışmadan bazıları şunlardır:

Ener ve Arıca (2011), 1985-2005 dönemini kapsayan süreçte Türkiye dahil $15 \mathrm{AB}$ ülkesi bağlamında işsizlik histerezisini panel birim kök testi ve Carrion-i Silvestre (2005) panel durağanlık testi ile analiz etmişlerdir. Çalışmanın ampirik bulguları analiz edilen ülkelerde histerezis hipotezinin geçerli olmadığını göstermiştir. Yazarlara göre bu sonuç geçici şokların istihdam üzerinde kalıcı değil geçici bir etkide bulunduğunu göstermektedir.

Güloğlu ve İspir (2011), 1988-2008 dönemini kapsayan çalışmalarında Türkiyedeki sektörel işsizliğin doğal işsizlik oranı ile mi yoksa işsizlik histerisi hipotezi ile açıklandığını tespit etmeye çalışmışlardır. Türkiye'deki 9 sektörün panel veri seti yöntemiyle durağanlığını sınamaya çalışmışlardır. Sonuç olarak genel teoriden farklı olarak Türkiye'deki sektörel işsizliğin işsizlik histerisi hipotezi ile değil doğal işsizlik oranı ile açıklanabilir olduğunu tespit etmişlerdir.

Onur (2011), Türkiye'de 1992-2009 dönemini kapsayan çalışmasında işsizlik üzerinde histeri etkisini araştırmış ve histeri olarak enflasyon hedeflemesinin etkilerini incelemiştir. Üç değişkenden oluşan (enflasyon, işsizlik, GSMH) regresyon modeli ve Granger nedensellik testi sonuçlarına göre enflasyon Türkiyéde 1 yll gecikme ile işsizliğin tek yönlü nedenidir. Ayrica GSMH-enflasyon arasinda 2 yil gecikmeyle çift yönlü nedensellik ilişkisi ortaya çıkmaktadır. Son olarak da işsizlik 3 yıllık gecikmeyle enflasyonun nedeni olmaktadır.

Yllancı (2009) Türkiye için işsizlik histerisinin varlı̆̆gnı yapısal kırılmalı birim kök testleri olan Peron, Zivot- Andrews (ZA) ve Lumsdaine-Papell (LP) ile araştırmıştır. Yazar, ZA ve LP testlerine göre Türkiyede işsizlik histerisinin geçerli olduğunu, yani zaman içerisinde meydana gelen şokların doğal işsizlik haddinde değişikliğe yol açtı̆̆ını ve doğal işsizlik haddi üzerinde kalıcı etki bıraktığı sonucuna varmıştır.

Türkiye için yapılan diğer çalışmalarda Pazarlığlu ve Çevik $(2005,2007), 1988-2004$ ve 1923-2005 arası 
Tablo 1. OECD ve AB Ülkelerinde İsssizlik Histerisi Üzerine Yapılan Çalışmalar

\begin{tabular}{|c|c|c|c|c|}
\hline Yazarlar & Ekonometrik Metot & Periyod & Ülke(ler) & İşsizlik Histerisi \\
\hline $\begin{array}{l}\text { Arestis ve Mariscal } \\
(2000)\end{array}$ & $\begin{array}{l}\text { Perron's (1997) } \\
\text { Birim kök testi }\end{array}$ & 1960Q1-1997Q2 & 22 OECD ülkesi & $\begin{array}{l}\text { Hayır: Avustralya, Belçika, Kanada, } \\
\text { Danimarka, Finlandiya Almanya, } \\
\text { Luxemburg, İsviçre, UK }\end{array}$ \\
\hline $\begin{array}{l}\text { Blanchard ve Summers } \\
\text { (1986) }\end{array}$ & $\begin{array}{l}\text { DF ve ADF Birim } \\
\text { kök testleri }\end{array}$ & $1953-1984$ & $\begin{array}{l}\text { Fransa, Almanya, UK } \\
\text { ve USA }\end{array}$ & Hayır: U.S. Evet: France, Almanya, UK \\
\hline Brunello (1990) & $\begin{array}{l}\text { DF birim kök } \\
\text { testleri }\end{array}$ & $1955-1987$ & Japonya & Evet \\
\hline Caarero ve diğerleri (2006) & $\begin{array}{l}\text { Yapısal kırılmalı } \\
\text { Birim kök testi }\end{array}$ & $1956-2001$ & 19 OECD ülkesi & Hayır \\
\hline Chang ve diğerleri. (2005) & Panel SURADF & 1961-1999 & $10 \mathrm{AB}$ ülkesi & $\begin{array}{l}\text { Hayır: Belçika ve Hollanda. } \\
\text { Evet: Diğer ülkeler }\end{array}$ \\
\hline Fève ve diğerleri. (2003) & ADF testi & 1966Q1-1999Q1 & 21 OECD ülkesi & $\begin{array}{l}\text { Hayır: Avustralya, Belçika, Kanada, } \\
\text { Danimarka, Finlandiya, Hollanda, } \\
\text { Norveç, USA. }\end{array}$ \\
\hline Everaert (2001) & $\begin{array}{l}\text { Tsay's (1988) } \\
\text { İntervention modeli }\end{array}$ & $1960-1999$ & 21 OECD ülkesi & Hayır \\
\hline Gray (2004) & $\begin{array}{l}\text { ADF ve KPSS } \\
\text { Birim kök testleri }\end{array}$ & $\begin{array}{l}\text { 1974M4- } \\
\text { 2002M12 }\end{array}$ & UK & Evet \\
\hline $\begin{array}{l}\text { Groenewold ve } \\
\text { Taylor (1992) }\end{array}$ & Yapısal Parametrele & 1966Q3-1988Q4 & Avusturalya & Hayır \\
\hline Hayashi (2005) & $\begin{array}{l}\text { Yamamoto (1996) } \\
\text { Augmented } \\
\text { step-wise } \\
\text { Chow test i }\end{array}$ & 1955Q1-1998Q2 & Japonya & Hayır \\
\hline $\begin{array}{l}\text { Leon-Ledesma ve McAdam } \\
\text { (2004) }\end{array}$ & $\begin{array}{l}\text { Yapısal kırılmalı ve } \\
\text { kırılmasız tek } \\
\text { değişkenli panel } \\
\text { birim kök testleri }\end{array}$ & 1991M1-2001M5 & $\begin{array}{l}12 \text { Orta ve Batı } \\
\text { Avrupa Ülkesi ve AB } \\
15 \text { ülkeleri }\end{array}$ & Hayır \\
\hline $\begin{array}{l}\text { Camarero ve Tamarit } \\
(2004)\end{array}$ & $\begin{array}{l}\text { Çok değişkenli } \\
\text { SURE birim kök } \\
\text { testleri }\end{array}$ & $1956-2001$ & 19 OECD ülkesi & $\begin{array}{l}\text { Evet: Avusturya, Almanya, İtalya, } \\
\text { Japonya, Norveç, Yeni Zelanda, } \\
\text { İsviçre. }\end{array}$ \\
\hline Mitchell (1993) & $\begin{array}{l}\text { Perron's (1989) } \\
\text { Birim kök testi }\end{array}$ & 1960s-1991Q3 & 15 OECD ülkesi & Evet \\
\hline Papell ve diğerleri. (2000) & $\begin{array}{l}\text { Zivot ve Verews } \\
\text { (1992) }\end{array}$ & $1955-1997$ & 16 OECD ülkesi & $\begin{array}{l}\text { Hayır: Belçika, Kanada, Danimarka, } \\
\text { Finlandiya, İrlanda, Norveç, İsveç } \\
\text {,İspanya, USA, UK. }\end{array}$ \\
\hline Røed (1996) & $\begin{array}{l}\text { maximum } \\
\text { likelihood } \\
\text { stationarty test }\end{array}$ & 1970Q1-1994Q4 & 16 OECD ülkesi & Hayır: USA \\
\hline Røed (2002) & $\begin{array}{l}\text { ADF ve KPSS } \\
\text { Birim kök testleri }\end{array}$ & $1960 \mathrm{~s}-1995$ & 10 OECD ülkesi & Hayır: USA. Evet: Diğer ülkeler \\
\hline Smyth (2003) & $\begin{array}{l}\text { LL ve IPS birim } \\
\text { kök testleri }\end{array}$ & 1983Q2-2002Q1 & Avusturalya & Evet \\
\hline Song ve $\mathrm{Wu}(1998)$ & $\begin{array}{l}\text { Panel birim kök } \\
\text { testi }\end{array}$ & 1972Q1-1992Q2 & 15 OECD ülkesi & Hayır \\
\hline
\end{tabular}

Kaynak: Lee ve Chang, 2008, s.312

dönemde, Barışık ve Çevik (2008) ise 1923-2006 arası dönemde Türkiye'deki işsizlik serisinin birim kök taşıdığını, durağan olmadığını, dolayısıyla işsizlik histerisinin geçerli olduğu sonucuna varmışlardır.

\section{Metodoloji}

$\mathrm{Bu}$ çalışmada işsizlik histerisinin varlığı panel birim kök testleri ile araştırılmaktadır. Yatay kesit bağımlılığına izin veren SURADF (Seemingly Unrelated Augmented Dickey Fuller) ve CADF (Cross-sectionally Augmented Dickey Fuller) panel birim kök testleri kullanılmaktadır. Bu testler ülkelerin işsizlik oranlarının durağan olup olmadığını ayrı ayrı test etme imkânı sağlamaktadır.
Breuer vd.(2002) tarafından geliştirilen SURADF, Zellner (1962) tarafından geliştirilen SUR (seemeingluy unrelated Regression) panel tahminine dayanan ADF (Augmented Dickey Fuller) testidir. SURADF aşağıdaki şekilde tanımlanmaktadır:

$$
\begin{aligned}
& \Delta y_{i t}=\alpha_{i}+\beta_{i} y_{i t-1}+\delta_{i t}+\sum_{j=1}^{p i} \varphi_{i j} \Delta y_{i t-j}+\vartheta_{i t} \\
& \operatorname{cov}\left(\vartheta_{i t}, \vartheta_{j t}\right) \neq 0, \quad i \neq j, \quad t=1,2,3 \ldots, T
\end{aligned}
$$

Burada her ülke için optimal gecikme uzunluğu $(\mathrm{p})$ farklı olmalıdır. (1) nolu model aslında her ülke için ayrı ayrı ADF birim kök testlerinin yapılacağını göstermektedir. Ülke sayısı N olmak üzere SUR sistemi şeklinde ADF testleri her ülke için şöyle yazılabilir: 


$$
\begin{aligned}
& \Delta y_{1 t}=\alpha_{1}+\beta_{1} y_{1 t-1}+\delta_{1 t}+\sum_{j=1}^{p 1} \varphi_{1 j} \Delta y_{1 t-j}+\vartheta_{1 t}, i=1 \\
& y_{2 t}=\alpha_{2}+\beta_{2} y_{2 t-1}+\delta_{2 t}+\sum_{j=1}^{p 1} \varphi_{2 j} \Delta y_{2 t-j}+\vartheta_{2 t}, i=2 \\
& \Delta y_{N t}=\alpha_{N}+\beta_{N} y_{N t-1}+\delta_{N t}+\sum_{j=1}^{p 1} \varphi_{N j} \Delta y_{N t-j}+\vartheta_{N t}, i=N
\end{aligned}
$$

SURADF yönteminde $\mathrm{N}$ adet temel hipotez ve $\mathrm{N}$ adet de alternatif hipotez her ülke için ayrı ayrı test edilir:

$$
\begin{aligned}
& H_{0}: \beta_{i}=0 \\
& H_{A}: \beta_{i}<0 \quad i=(1,2,3 \ldots, N)
\end{aligned}
$$

SURADF testi her birim için ayrı birim kök testi prosedürü uygulamakta, panelde yer alan serilerden kaçının durağan olduğunun bilgisini vermekte ve durağan serilerin hangi birime ait olduğunu söyleyebilmektedir. Bu yönüyle SURADF birim kök testi diğer panel birim kök testlerinden ayrışmaktadır. SURADF test değeri, 10.000 tekrarlı Monte Carlo Simülasyonundan elde edilen bootstrap kritik değerlerinden büyükse, temel hipotez ret edilir ve ilgili birime ait serinin durağan olduğuna yani birim kök içermediğine karar verilir. Ayrıca bu yöntemin uygulanabilmesi için $\mathrm{T}>>\mathrm{N}$ olmalıdır.

Bu çalışmada uygulanan ikinci panel birim kök testi Pesaran (2006) tarafından geliştirilen CADF (Crosssectionally Augmented Dickey Fuller) testidir. Test prosedürü, paneli oluşturan zaman serilerinin ortak bir bileşene sahip oldukları argümanına dayanmaktadır. (1) denkleminin hata terimi, ortak ve bireysel etkilerin bileşkesi olarak aşağıdaki gibi yazılabilir (Pesaran, 2006; Güloglu ve İvrendi, 2008, s. 3): $\mu_{i t}=\gamma_{i} f_{t}+\varepsilon_{i t}$

Bu denklemde $f_{t}$ birimler arası gözlenemeyen ve sabit olduğu varsayılan "ortak etkileri"; $\varepsilon_{i t}$ ise zamana ve birimlere göre iid (independent, identically distributed ) olan bireysel etkileri yansıtmaktadır:

$$
\varepsilon_{i t}=\rho_{i} \varepsilon_{i t-1}+\omega_{i t}, \quad\left|\rho_{i}\right|<1
$$

Gecikmeli yatay kesit ortalamaları ve birinci farkların varlığı bir faktör yapısı yoluyla birimler arası korelasyonu hesaba katmaktadır. $\mu_{i t}$ hata teriminde var olmas1 muhtemel otokorelasyon $\bar{y}_{t-1}$ ve $\Delta \bar{y}_{t-1}$ gecikmeli değerleri ile genişletilmektedir. Bu yöntemde birimler arası korelasyon, gecikmeli yatay kesit ortalamaları ve birinci farkların varlığıyla birimler arası korelasyonu hesaba katmaktadır (Tatoğlu, 2012, s. 224). Bir diğer deyişle CADF testinde, bildiğimiz ADF regresyonunun gecikmeli yatay kesit ortalamaları ile genişletilmiş hali kullanılmaktadır. Bu anlatılanlar doğrultusunda CADF için kurulan regresyon modeli aşağıda kurulan regresyonun OLS ile tahmin edilmesine indirgenmiş olur (Pesaran, 2006, s. 269):

$$
\Delta y_{i t}=a_{i}+b_{i} y_{i t-1}+c_{i} \bar{y}_{t-1}+\sum_{j=1}^{p_{i}} d_{i j} \Delta \bar{y}_{t-j}+\sum_{j=0}^{p_{i}} n_{i j} \Delta \bar{y}_{i t-j}+e_{i t}
$$

Burada $\bar{y}_{t}$, tüm $\mathrm{N}$ gözlemlerinin zamana göre ortalamasıdır. Elde edilen CADF test istatistiklerini, Pesaran (2006) kritik tablo değerleriyle karşılaştırarak her ülke için durağanlık testinin sonuçlarını ayrı ayrı değerlendirilmektedir. Bu eşitlikte birim kök testi hipotezleri şu şekildedir:
$H_{0}: b_{i}=0$, tüm $\mathrm{i}=1,2,3 \ldots, \mathrm{N} \quad$ ve

$H_{1}: b_{i}<0, \mathrm{i}=1,2,3 \ldots, \mathrm{N}_{1}, \quad b_{i}=0, \mathrm{i}=\mathrm{N}_{1}+1, \mathrm{~N}_{1}+2, \ldots, \mathrm{N}$

Pesaran'a göre, CADF testi, hem $\mathrm{N}>\mathrm{T}$ hem de $\mathrm{T}>\mathrm{N}$ durumlarında geçerlidir. Ancak hem $\mathrm{T}$ hem de $\mathrm{N}$ yeterince büyük olmalıdır. 


\section{Veri}

$\mathrm{Bu}$ çalışmada işsizlik oranı, işsizlerin, istihdam edilen ve edilmeyen toplam işgücüne oranı şeklinde tarif edilmektedir. İşsizlik oranlarına ait veriler 1980-2012 arası dönemi kapsayan 12 Euro bölgesi ülkesine aittir: Avusturya, Belçika, Almanya, Yunanistan, Irlanda, Italya, Hollanda, Finlandiya, Portekiz, İspanya, Fransa, Lüksemburg. Bütün veriler Dünya Bankasının "World Development Indicators" veri setinden temin edilmiştir. Ülkelerin işsizlik oranları aşağıda Şekil 1'de sunulmaktadır. İşsizlik oranlarının İspanya ve İrlanda hariç genel olarak \% 3-10 bandında dönemsel dalgalanmalar göstererek 2008 yılına kadar durağan bir görüntü sergileyerek geldiği; 2008 yılından sonra ise başta Yunanistan, Portekiz ve İspanya olmak üzere bütün Euro ülkelerinde işsizliğin artış trendine girdiği görülmektedir. Bu betimsel bulgular bundan sonraki bölümde ekonometrik yöntemlerle formel olarak test edilecektir.

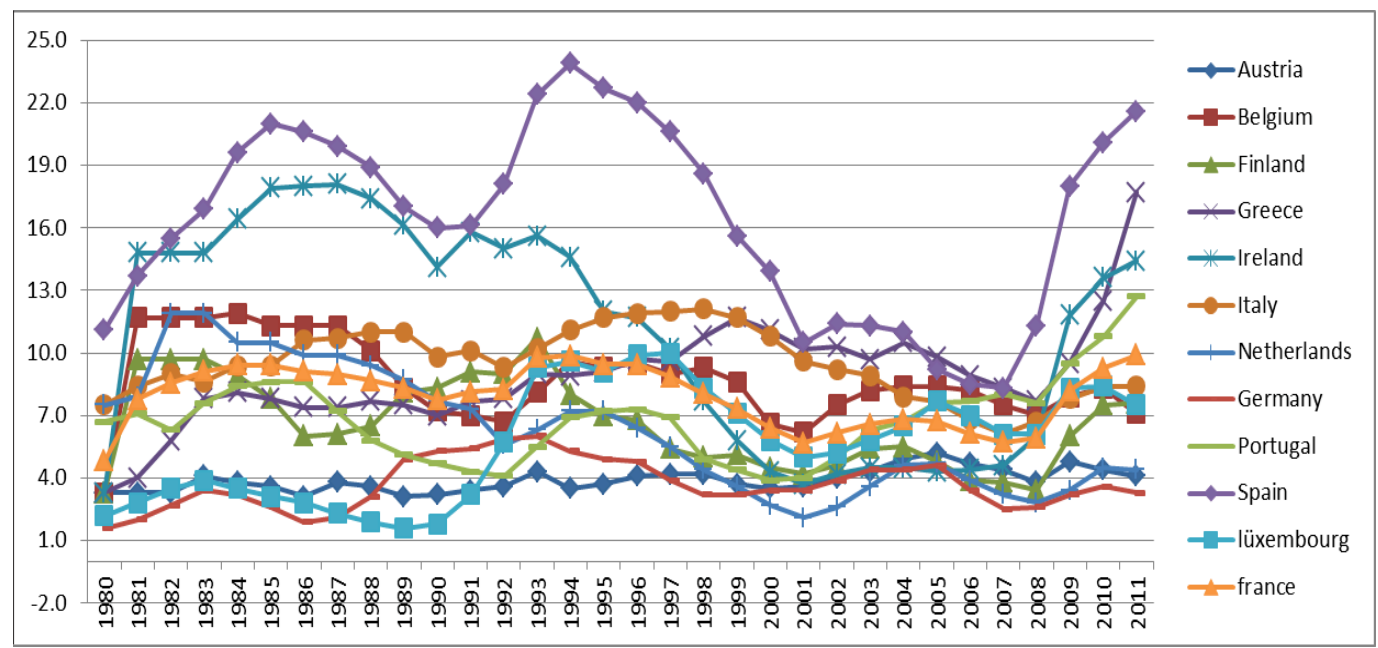

Kaynak: Dünya Bankası "World Development Indicators"

Şekil 1. Euro Bölgesi Ülkelerinin Işsizlik Oranları

\section{Ampirik Analiz}

Çalışmanın bu bölümünde Breuer ve vd. (2002) tarafından geliştirilen SURADF ve Pesaran (2006) tarafından geliştirilen CADF panel birim kök sınama yöntemleri, işsizlik verilerine uygulanmaktadır. Ancak yukarıda anlatılan ikinci nesil panel birim kök testlerinin uygulanabilmesi için öncelikle yatay kesit bağımlılığının test edilmesi gerekmektedir. Birinci nesil panel birim kök testleri paneli oluşturan yatay kesit birimlerinin birbirinden bağımsız olduğu varsayımı altında geliştirilmişlerdir. Temel hipotezin durağan olmadığı bu testlere Im, K., Pesaran, H. ve Shin, Y. (2003), Maddala ve Wu (1997), Levin,Lin ve Chu (2002), Hadri (2000) ve Choi (2001) sinamaları örnektir. Bu sınamaların ortak varsayımı yatay kesit bağımsızlığıdır (Güloğlu ve İspir, 2011, s. 210). $\mathrm{Bu}$ kuvvetli varsayımın sinanması ve buna göre birim kök testinin tercih edilmesi gerekmektedir. Bu yüz- den birinci nesil birim kök testlerini uygulamadan önce yatay kesit bağımsızlığı testi uygulanmaktadır. $\mathrm{Bu}$ çalışmada yatay kesit bağımsızlığı, Breusch- Pagan (1980) CDLM1ve Pesaran (2004) CDLM2 ve CDLM testleri ile sinanmaktadır. Zaman boyutunun yatay kesit boyutundan büyük olduğu durumda $(\mathrm{T}>\mathrm{N})$ CDLM1, T ve N’nin yeterinde büyük olduğu durumlarda CDLM2 testi ve $\mathrm{T}<\mathrm{N}$ olduğu durumda da CDLM testi kullanılmaktadır. Bizim örneğimizde $\mathrm{T}=32$ ve $\mathrm{N}=12$ olduğu için, $\mathrm{T}>\mathrm{N}$ ve $\mathrm{T}$ ve N'in yeterince büyük olma koşulları sağlanmaktadır. CD testleri ve t istatistikleri Tablo 2'de sunulmaktadır. CDLM1 ve CDLM2 test istatistiklerinden yatay kesitler arasındaki korelasyonların olukça anlamlı çıktığı görülmektedir. CDLM testi ise anlamlı çıkmamıştır. Bunun sebebi de bu testin $\mathrm{T}>\mathrm{N}$ durumunda geçerli olmamasıdır. Buna göre Euro Bölgesindeki 12 ülkenin işsizlik verilerinde yatay kesit bağımlılığı vardır. 
Tablo 2. Yatay Kesit Bağımlılığı Test Sonuçları

\begin{tabular}{lll}
\hline CD Testleri & t-istatistiği & Olasılık \\
\hline LM1 (Breusch,Pagan 1980) & 1296.848 & 0.0000034 \\
LM2 (Pesaran 2004) & 56.780 & 0.0000012 \\
LM (Pesaran 2004) & 25.783 & 0.1084603 \\
\hline
\end{tabular}

Yatay kesitlerde bağımlılık çıktığı için bu çalışmada işsizlik serisindeki durağanlığı test etmek için kullanılacak birim kök testleri ikinci nesil panel birim kök testleridir. Bu doğrultuda uygulanan SURADF ve CADF test sonuçları Tablo 3'te yer almaktadır. SURADF sonuçları tablonun sol tarafında yer almaktadır. Kritik değerler Monte Carlo simülasyonuyla elde edilmiştir. SURADF sonuçlarına göre 9 ülkenin işsizlik serisinde sıfır hipotezi ret edilmekte ve serinin durağan olduğu yani birim kök içermediği sonucuna varılmaktadır. Bu ülkeler Belçika, Almanya, İrlanda, İtalya, Hollanda, Finlandiya, İspanya, Fransa ve Lüksemburg'dur. İşsizlik serisi durağan olmayan yani birim kök içeren ülkeler ise Avusturya, Yunanistan ve Portekiz'dir.
Tablo 3'ün sağ tarafında verilen CADF test sonuçları SURADF ile elde edilen sonuçları genel itibari ile doğrulamaktadır. CADF testi, işsizlik serilerinde birim kök olduğunu ileri süren hipotezi sadece 3 ülke için ret edememektedir. Bu ülkeler Yunanistan, İrlanda ve Avusturya'dır. Öte yandan 9 ülkede işsizlik serisinin durağan olduğu kabul edilmektedir: Belçika, Almanya, İtalya, Hollanda, Finlandiya, İspanya, Portekiz, Fransa ve Lüksemburg'dur. Portekiz, İrlanda ve Yunanistan için bu iki test farklı sonuç vermektedir.

Portekiz ve İrlanda için CADF ve SURADF testleri farklı sonuçlar vermiştir. Bunun olası sebeplerinden bir tanesi SURADF testinin bir sistem çözümlemesi şeklinde diğer ülkelerin hata terimlerini de dikkate alarak katsayıları tahmin etmesine karşın CADF testinde böyle bir durumun söz konusu olmamasıdır.

Tablo 3. SURADF ve CADF Test Sonuçları

\begin{tabular}{|c|c|c|c|c|c|c|c|}
\hline Ülkeler & SURADF & $\% 1$ & $\% 5$ & $\% 10$ & $\bar{P}$ & $\overline{\text { CADF }}$ & $\mathbf{P}$ \\
\hline Avusturya & -3.395 & -5.487 & -4.464 & -3.945 & 3 & -2.698 & 3 \\
\hline Belçika & $-5.617^{*}$ & -5.75 & -4.803 & -4.334 & 2 & $-4.212 *$ & 2 \\
\hline Almanya & $-5.173 * *$ & -6.18 & -5.619 & -4.944 & 2 & $3.271 * *$ & 2 \\
\hline Yunanistan & -5.723 & -7.753 & -6.795 & -6.129 & 2 & -2.111 & 2 \\
\hline İrlanda & $-6.085^{* *}$ & -7.487 & -6.047 & -5.635 & 2 & -2.751 & 2 \\
\hline İtalya & $-5.902 * *$ & -6.286 & -5.352 & -4.677 & 2 & $-5.149 *$ & 2 \\
\hline Hollanda & $-4.528 * *$ & -5.872 & -4.424 & -3.820 & 2 & $-4.741^{*}$ & 2 \\
\hline Finlandiya & $-4.96^{* *}$ & -6.28 & -4.948 & -4.410 & 2 & $-3.788 * *$ & 2 \\
\hline Portekiz & -3.862 & -6.713 & -5.514 & -4.944 & 2 & $-4.073 * *$ & 2 \\
\hline İspanya & $-4.751 * *$ & -5.887 & -4.708 & -4.060 & 2 & $-4.360 *$ & 2 \\
\hline Fransa & $-5.077^{*}$ & 1.757 & 2.600 & 3.053 & 6 & $-5.630^{*}$ & 6 \\
\hline Lüksemburg & $-5.000 * *$ & -5.06 & -4.500 & -3.983 & 3 & $-4.698^{*}$ & 3 \\
\hline
\end{tabular}

Notlar: ${ }^{* * *}{ }^{* *} \mathrm{ve}^{*}$ sırasıly \% 10, 5 ve 1 anlamlılık düzeylerini göstermektedir.

SURADF için 10.000 döngüyle Monte Carlo Simülasyonundan elde edilen bootstrap kritik değerleri kullanılmıştır.

Gecikme uzunlukları (p) Schwarz bilgi kriterine göre seçilmiştir.

CADF testi için kritik değerler Pesaran (2006), Tablo 1c'den elde edilmiștir. Bu kritik değerler \% 1, 5 ve 10 için sırasılyla $-4.11,-3.36,-2.97$ şeklindedir. 
Böylece ikinci nesil birim kök testleri sonucunda, işsizlik serisinin büyük çoğunlukla birim kök içermediği yani durağan olduğu görülmektedir. Bu sonuçlarin iktisadi anlamlı CADF ve SURADF sinamalarının işsizlik histerisi önsavını desteklemediği şeklindedir. $\mathrm{Bu}$ bulgular iki sonuca işaret etmektedir. Birincisi, ekonomide yaşanan şoklar ve uygulanan istikrar politikaları, işsizliğin doğal oranında kalıcı değişimler meydana getirmemiştir. İkincisi de işsizliğin incelenen zaman periyodu boyunca sabit bir ortalama etrafinda ve durağan bir yapıda hareket ettiğini göstermektedir.

Özetle, bu çalışmada elde edilen sonuçlar işsizlik serisinde birim kök olmadığı savını desteklemektedir. Uygulanan ekonometrik sonuçlara göre işsizlik serisi birçok Euro Bölgesi ülkesinde durağan bir süreç izlemektedir. Çalışmanın ampirik bulgularına göre sadece İrlanda, Avusturya, Yunanistan ve Portekiz'de histerezis hipotezi geçerlidir. Bu ülkelerde şoklar istihdam üzerinde kalıcı etkiler bırakırken, diğer ülkelerde meydana gelen şokların istihdam üzerindeki etkisi kalıcı değil geçici bir nitelik taşıma potansiyeline sahiptir. Ancak küresel krizin etkisi henüz tam ortaya çıkmadığından bu etkinin ilerde kalıcı olup olmayacağ 1 Avrupa'da devam eden borç krizinin şiddetine ve süresine bağlı olarak değişiklik gösterecektir. Bir diğer deyişle mevcut zaman dilimi için ülkelerin çoğunda histeri önsavına karşı doğal işsizlik oranı önsavı geçerli çıkmıştır. Ayrıca 2008 küresel kiriz işsizlik oranlarında henüz petrol şokuna benzer bir kalıcı etkiye sebep olmamıştır. Şoklar şimdilik geçicidir. Bu sonuçlar Camarero ve Tamarit (2004), Feve vd. (2003), Arestis ve Mariscal (2000) ve Chang vd. (2005) ile paralellik arz etmektedir.

\section{Sonuç}

Bu çalışmada Eurơyu 1999 yilından bu yana kullanan $12 \mathrm{AB}$ ülkesinin işsizlik oranlarının histerisi etkisi gösterip göstermedi, durağan olup olmadığı, 19802012 arası dönemde birimler arasındaki yatay kesit bağımlılı̆̆ını dikkate alan ikinci nesil panel birim kök testleri ile araştırılmaktadır. İşsizlik serilerine gelen şoklarla ilgili Blanchard ve Summers'in (1986) şok- ların kalıcı olduğunu öne sürdükleri "işsizlik histerisi” önsavı ve Friedman ve Phelps'in (1968) şokların geçici olduğunu öne sürdükleri "doğal işsizlik oranı” önsavları bu çalışmada test edilmektedir.

Çalışmanın ampirik bulgularına göre histeri hipotezi sadece Yunanistan, Portekiz, İlanda ve Avusturya'da geçerlidir. $\mathrm{Bu}$ ülkelerde geçici şoklar kalıcı etkiler birakmamaktadır. Camarero ve Tamarit (2004) ve Arestis ve Mariscal (2000) çalışmaları da bu argümanı destekler mahiyettedir. Doğal işsizlik oranı hipotezi ise kalan 9 ülkede () geçerlidir. Yani şoklar, özellikle 2008 küresel krizinin şokları henüz istihdamda yapısal dönüşümlere yol açmamıştır.

Özetle, bu çalışmada elde edilen sonuçlar işsizlik serisinde birim kök olmadığı savını desteklemektedir. Uygulanan ekonometrik sonuçlara göre işsizlik serisi birçok Euro Bölgesi ülkesinde durağan bir süreç izlemektedir. Çalışmanın ampirik bulgularına göre sadece İrlanda, Avusturya, Yunanistan ve Portekiz'de histerezis hipotezi geçerlidir. Bu ülkelerde şoklar istihdam üzerinde kalıcı etkiler bırakırken, diğer ülkelerde meydana gelen şokların istihdam üzerindeki etkisi kalıcı değil geçici bir nitelik taşımaktadır. Ayrıca, 2008 küresel krizinin yarattığı işsizliğin henüz tüm ülkelerde yapısal ve kronik bir hal almadığı ancak ilerleyen süreçte bu yüksek düzeylerde seyreden işsizlik oranlarının çok sayıda ülkenin doğal işsizlik oranını yukarı çekeceği ve histerezis etkisinin kıta Avrupası genelinde görülmeye başlanabileceği öngörülmektedir. Bu bağlamda işsizliği azaltıcı ve işsiz geçirilen sürenin kısaltılması adına yeni istihdam politikalarının hayata geçirilmesi önem arz etmektedir.

\section{Kaynakça}

Ayala, A. (2012). Unemployment Hysteresis: Empirical Evidence for Latin America, Journal of Applied Economics, Vol XV, No. 2, 213-233

Arestis, P., Mariscal, I. (2000). OECD Unemployment: Structural Breaks and Stationarity. Applied Economics, 32 (4), 399-403. 
Barışık, S., Çevik, E. İ. (2008). İşsizlikte Histeri Etkisi: Uzun Hafıza Modelleri. Kamu İs, 9(4), 1-36

Blanchard, O.J., Summers, L. (1986). Hysteresis and the European unemployment problem. In: S. Fischer (ed.), NBER Macroeconomics Annual, Cambridge, MIT Press.

Becker, R., Enders, W., Lee, J. (2006). A stationarity test in the presence of an unknown number of smooth breaks. Journal of Time Series Analysis 27 (3), 381-409

Breuer, B., McNown, R., Wallace, M. (2002). Seriesspecific unit root test with panel data. Oxford Bulletin of Economics and Statistics, 64, 527-46.

Breusch, T. and Pagan, A. (1980) The Lagrange multiplier test and its application to model specifications in econometrics. Reviews of Economics Studies, 47, 239-53.

Brunello, G. (1990). Hysteresis and "the Japanese unemployment problem": a preliminary investigation. Oxford Economic Papers, 42(3), 483-500.

Camarero, M., Tamarit, C. (2004). Hysteresis vs. natural rate of unemployment: new evidence for OECD countries. Economics Letters, 84(3), 413-417.

Camarero, M., Carrion-i-Silvestre, J. L., Tamarit, C. (2006). Testing for Hysteresis in Unemployment in OECD Countries: New Evidence using Stationarity Panel Tests with Breaks. Oxford Bulletin of Economics and Statistics, 68(2), 167-182.

Chang, T., Nieh, K.C., Wei, C.C. (2005). An empirical note on testing hysteresis in unemployment for ten European countries: panel SURADF approach. Applied Economics Letters 12, 881-886.

Chang, T. ( 2011). Hysteresis in unemployment for 17 OECD countries: Stationary test with a Fourier function. ScienceDirect Economic Modelling, 28, 2208-2214

Christopoulos, D.K., Leon-Ledesma M. (2007). Unemployment Hysteresis in EU Countries: What do We Really Know About it? Journal of Economic Studies, 34(2), 80-89.

Choi, I. (2001). Unit roots tests for panel data. Journal of International Money and Finance, 20, 229-72.
Ener, M. And Arıca, F. (2011). Unemployment Hysteresis in Turkey and 15 EU Countries: A Panel Approach. RJEBI, Volume 1, 65-71

Feve, P., Henin, P. Y., Jolivaldt, P. (2003). Testing for hysteresis: unemployment persistence and wage adjustment. Empirical Economics, 28(3), 535-552.

Friedman, M. (1968). The Role of Monetary Policy. American Economic Review, 58, 1-17.

Güloğlu, B. ve İspir, M., S. (2011). Doğal İşsizlik Oranı mı? İşsizlik Histerisi mi? Türkiye İçin Sektörel Panel Birim Kök Sınaması Analizi, Ege Akademik Bakış Dergisi, 11(2), 205-215

Güloğlu, B. ,İvrendi, M. (2008). Output fluctuations: transitory or permanent? the case of Latin America. Applied Economic Letters 17(4), 381-386.

Hadri, K. (2000). Testing for stationarity in heterogenous panels, Econometrics Journal, 3, 148-61

Im, K., Pesaran, H., Shin, Y. (2003). Testing for unit roots in heterogenous panels. Journal of Econometrics, 115, 53-74.

Levin, A., Lin, C., Chu, J., Shang, C. (2002) Unit roots tests in panel data:asymptotic and finite sample properties. Journal of Econometrics, 108, 1-24

Lee, C-C., Chang, C-P. (2008). Unemployment hysteresis in OECD countries: Centurial time series evidence with structural breaks. ScienceDirect Economic Modelling, 25, 312-325

Liew, V., K-S., Chia, R., C-J., Puah, C-H. (2009). Does Hysteresis in Unemployment Occur in OECD Countries? Evidence from Parametric and NonParametric Panel Unit Roots Tests, MPRA Munich Personal RePEc Archive, MPRA Paper No. 9915, posted 25, http://mpra.ub.uni-muenchen.de/9915/

Maddala, G. S. and Wu, S. (1997). A comparative study of unit root tests with panel data and a new simple test, Ohio State University, Working Paper.

Onur, S. (2011). Türkiye Ekonomisinde İşsizlik Histerisi (1992-2009), Namık Kemal Üniversitesi Sosyal Bilimler Enstitüsü Dergisi, No:04

Pazarlıŏlu, M. V., Çevık, E.İ. (2007). Ratchet Model: 1939-2005 Dönemi Türkiye Uygulaması. Trakya Üniversitesi Sosyal Bilimler Dergisi, 9(1), 17-34 
Pesaran, H. (2004). General diagnostic tests for cross section dependence in panels, Working Paper No: 0435, University of Cambridge.

Pesaran, H. (2006). A simple panel unit root test in the presence of cross section dependence, Cambridge University, Working Paper, No: 0346.

Phelps, E.S. (1968). Money-wage Dynamics and Labor-market Equilibrium, Journal of Political Economy, 76(4), 678-711.

Phelps, E. (1994). Structural Slumps: The Modern Equilibrium Theory of Unemployment, Interest, and Assets, Cambridge, Harvard University Press

Strazicich, M. C., Tieslau, M., Lee, J. (2001). Hysteresis in unemployment? Evidence from panel unit root tests with structural change. Unpublished manuscript, University of North Texas.

Tatoğlu, F.Y (2012). İleri Panel Veri Analizi, Beta Yay1nevi, İstanbul

Yllancı, V. (2009). Yapısal Kırılmalar Altında Türkiye İçin İşsizlik Histerisinin Sınanması, Doğuş Üniversitesi Dergisi, 10 (2), 324-335

Zellner, A. (1962). An Efficient Method of Estimating Seemingly Unrelated Regressions and Tests for Aggregation Bias. Journal of the American Statistical Association, 57, 348-368. 